\title{
Introduction: Historical and Comparative Macrosociology of Middle Eastern Legal Systems
}

OÑATI SOCIO-LEGAl SERIES VOluME 10, ISSUE 5 (2020), 955-959: HistoriCAL AND COMPARATIVE

MACROSOCIOLOGY OF MIDDLE EASTERN LEGAL SYSTEMS

DOI LINK: HTTPS://DOI.ORG/10.35295/OSLS.IISL/0000-0000-0000-1126

RECEIVED 13 MAY 2020, ACCEPTED 14 MAY 2020

\author{
NATHAN J. BROWN* (D) \\ SAÏD A. ARJOMAND*
}

\section{Abstract}

The understanding of law in the Middle East requires not simply different disciplinary perspectives but bringing disciplines into dialogue with each other. It also requires analysis that crosses historical periods in order to understand legal systems as ones that develop over time based on longstanding traditions and earlier transformations, not simply European intrusion. We present a series of analyses by scholar who, while anchored in their own discipline, historical focus, and geographical specialization consciously work to address a broad social scientific audience.

\section{Key words}

Law; Middle East; macrosociology; macrohistory; Islam

\section{Resumen}

La comprensión del derecho en Oriente Medio no sólo requiere perspectivas disciplinarias diferentes, sino también poner esas disciplinas en diálogo mutuo. También requiere un análisis que atraviese períodos de la Historia para entender sistemas jurídicos como aquéllos que se desarrollan en el tiempo basados en largas tradiciones y transformaciones anteriores, no solo en la intrusión europea. Presentamos una serie de análisis de expertos que, aun enraizados cada uno en su disciplina, enfoque histórico y especialización geográfica, trabajan conscientemente para dirigirse a una audiencia científica socialmente amplia.

\footnotetext{
* Author of Arguing Islam after the Revival of Arab Politics (Oxford University Press, 2017). Professor of Political Science and International Affairs, Department of Political Science, George Washington University, Washington, DC 20052. Email address: nbrown@gwu.edu

* Author of Revolution: Structure and Meaning in World History (The University of Chicago Press, 2019). Distinguished Professor of Sociology Emeritus, Stony Brook University, Stony Brook, NY 11794-4356. Email address: said.arjomand@stonybrook.edu
} 
Palabras clave

Derecho; Oriente Medio; macrosociología; macrohistoria; Islam 


\section{Introduction}

Understanding the intellectual, sociological, and political aspects of law in the Middle East has been hampered by an unfortunate and outmoded disciplinary divide. Social scientists - chiefly in the fields of political science, sociology, and some legal studies have focused much of their attention on modern structures, probing how laws are written, courts are structured and adjudicate, citizens litigate, and regimes deploy law as an instrument. Scholars from these disciplines often encounter intellectual approaches, doctrines, and ideas that are deeply rooted historically, many (but not all) of a religious provenance, with a strong influence of the scholarship on Islamic law. These disciplines stress generalization at the expense of diversity and causal inference at the expense of path dependency. They yield insights that are broad. But they are often less well equipped to go beyond a fairly superficial understanding of history and doctrine, as even those scholars who are friendly to such subjects are entirely reliant on secondary sources.

At the same time, those who approach law from an area studies viewpoint or from various disciplines more anchored in the humanities and more interpretive social sciences (such as religious studies, history, and anthropology) excel with the study of texts, intellectual history, legal thought, and the premodern period. But the questions they ask tend to be resistant to generalization and comparative analysis; and when they do make forays into the modern period (as anthropology does), it is generally to develop rich but highly contextualized understanding.

That is beginning to change. Over the past decade, an increasing number of individual scholars have ventured across the divide. Some social scientists have begun to develop the skills and the expertise to understand the classical intellectual traditions even while retaining their focus on modern controversies, institutions, and practices. Some of those trained more in the classical traditions have sought to explore current debates and issues, often guided by social-science writings in this endeavor.

Last but not least, the generally accepted view of the transformation of Middle Eastern legal system as the product of the political impact of the Western legal tradition will be supplemented by the much neglected earlier transformations of the Middle Eastern legal systems under the impact of such historical watersheds in the Islamic era as the 'Abbasid revolution and the Mongol invasion.

Our aim is to bring together a group of scholars who have made individual forays toward bridging this gap. We aim to encourage cross-fertilization and cross-disciplinary work in a collaborative fashion, but we do not pretend to offer a comprehensive new understanding of the politics and sociology of law in the modern Middle East. Instead we reach for insight by offering a range of scholarship from those anchored in their own disciplines, questions, and methods who are still friendly to - and anxious to converse with - those pursuing other interests or with different tools at their disposal.

We have deliberately crossed not only disciplinary boundaries but temporal ones and geographic borders. We do the first by presenting contributions that either cover a broad historical sweep or consciously root an understanding of one era in broader historical perspective. And we do the second by covering Iran, Egypt, and Oman, all societies in 
which Islamic legal traditions exist in diverse forms and serve as frames or vehicles for political and social struggles.

And those struggles are not marginal. The relevance of intellectual, religious, and cultural traditions and approaches to the study of current Middle Eastern societies seems obvious and is particularly strong in the legal realm. Virtually all of the current areas of contention in Middle Eastern societies have a legal dimension, and disputes over law (what it means, how it is derived, who determines its content, how it is applied) often lie at the center of politics. But scholars have been poorly equipped in the past, with disciplines speaking past each other on such subjects.

Historian Knut S. Vikør, for instance, selects a legal and intellectual tradition that often gets overlooked in treatments of Middle Eastern and Islamic legal traditions: Ibadism. He provides an extremely broad survey of Ibadi history - a history unknown even to many regional specialists but not merely to render it more familiar. He also maps the interaction of that tradition with some very different political and social circumstance (for instance as an officially favored approach in Oman and as a marginal community in North Africa). Political scientist Nathan J. Brown examines conceptions of political authority, noting how those deploying a political vocabulary rooted in Islamic intellectual traditions use the phrase "wali al-amr" to refer to the ruler, thus tucking the emergence of a modern bureaucratic state - unanticipated in those traditions - out of sight but hardly irrelevant.

In terms of religio-legal diversity, three major Islamic traditions, the Sunni, Shi $i$, and Ibadi (which, while much smaller, stands outside the two larger branches), are represented in this volume. Brown shows how Egypt, belonging to the Sunni, mainstream Islam has sought to graft a term for authority derived from Islamic law into the legal framework of its modern nation-state. Vikør analyzes the historical development of Islamic jurisprudence in the Ibadi branch of the Kharijite Islam. The remaining three papers are on Iran, the most populous Shi'ite nation of the Muslim world. Together, these papers show the path dependency of state-building and legal modernization in the Middle East. In fact, sociologist Saïd Amir Arjomand's macrohistorical survey shows the common path dependency of the Islamicate legal transformation of modern Egypt and Iran, building on the earlier complex of the TurkoMongolian law and the Shari'a reconciliation in the early modern era.

Arjomand ends his historical analysis by emphasizing how late in the nineteenth century legal modernization the notion of citizenship was introduced and how small was its effect. The "people of Iran" (ahl-e Irān) mentioned in the international treaties since the eighteenth century constituted the nation of Iran whose sovereignty was declared in Iran's first Constitution of 1906-7 - where the subjects of the Shah became those of the nation-state of Iran.

Hadi Enayat, a political sociologist, takes up the conception of citizenship in the legal modernization of Iran under constitutional monarchy (1906-1979), He examines the legal reforms triggered by Iran's Constitutional Revolution of 1906 in a historical and comparative perspective, viewing personhood in the Western and Islamic legal traditions as well as current debates in legal studies theoretically, and the historical background off the chaotic legal order of Qajar Iran (1794-1906) historically. Analyzing 
the Constitution, civil and penal laws of the Pahlavi era, he argues that they nurtured conflicted notions of subjectivity and citizenship.

Kian Tajbakhsh, a social scientist with a training in urban planning, also focuses on Iran. Chronologically, he begins where Enayat left off and traces the evolution, and transformation of local government and its law under the Islamic Republic of Iran established in 1979. Tajbakhsh analyzes another important dimension of nation-statebuilding in Iran that had not received much attention in the étatiste legal modernization of the Pahlavi era by focusing on three arenas of contention at the local level: the scope of political participation, the degree of legislative authority, and the degree of fiscal authority.

The papers included in this volume were originally presented at the workshop on Historical and Comparative Macrosociology of Middle Eastern Legal Systems at the International Institute for the Sociology of Law, Oñati, Spain, May 24-25, 2018. The workshop was organized by Nathan J. Brown of George Washington University and Saïd Amir Arjomand while he was the Senior Research Associated of Kollg Forschungsgruppe Multiple Secularities at the University of Leipzig. Arjomand wishes to acknowledge the support of the Multiple Secularities KFG for organizing the workshop and writing his own paper for it. 